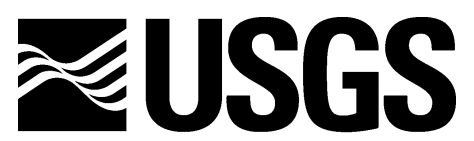

science for a changing world

In Cooperation with the World Bank, the Islamic Republic of Mauritania, and Futures Group

\title{
Hydrogeology of the Islamic Republic of Mauritania
}

By Michael J. Friedel and Carol Finn

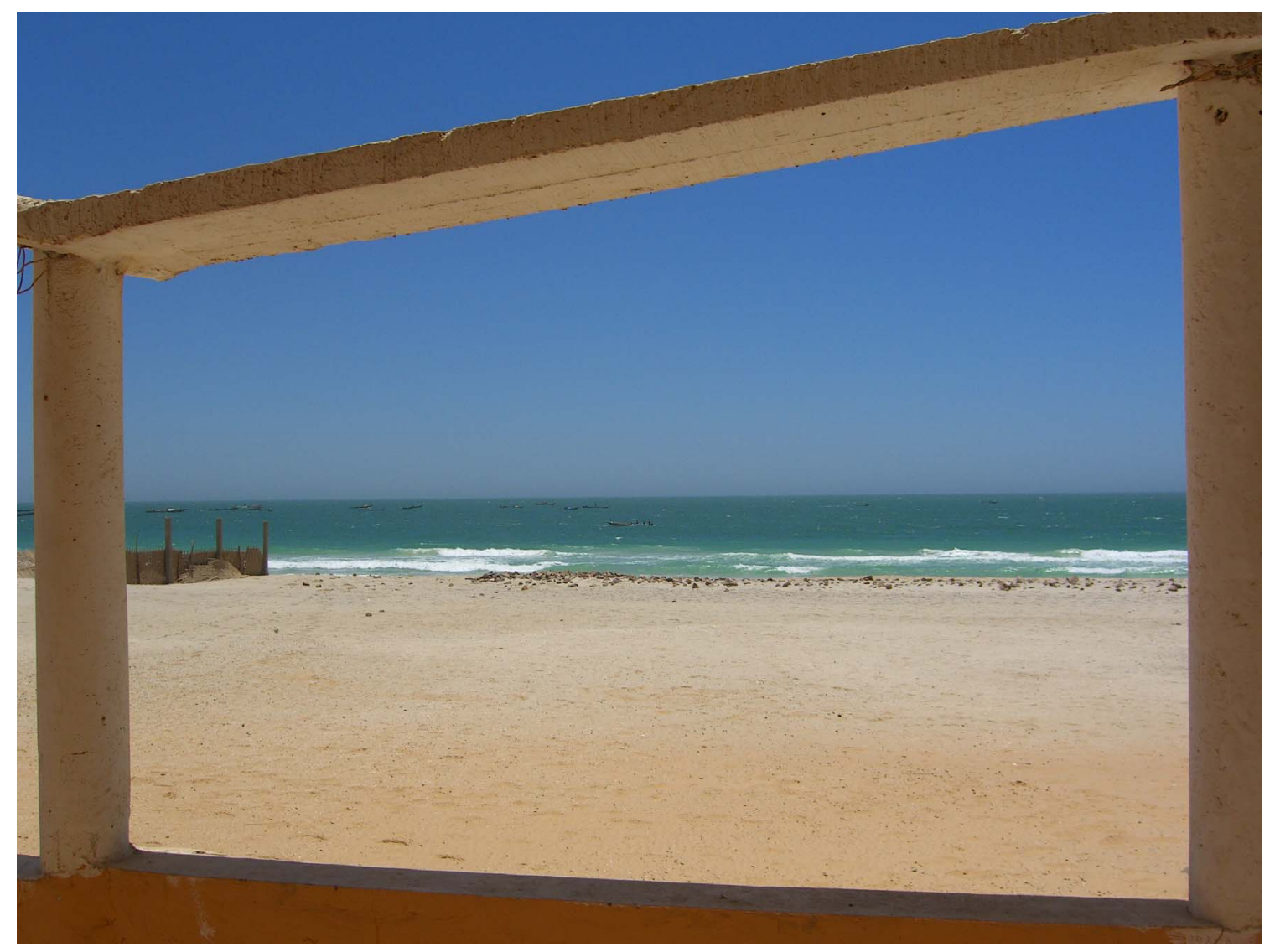

Open-File Report 2008-1136

U.S. Department of the Interior

U.S. Geological Survey 


\title{
U.S. Department of the Interior DIRK KEMPTHORNE, Secretary
}

\section{U.S. Geological Survey \\ Mark D. Myers, Director}

\author{
U.S. Geological Survey, Reston, Virginia 2008
}

For product and ordering information:

World Wide Web: http://www.usgs.gov/pubprod

Telephone: 1-888-ASK-USGS

For more information on the USGS - the Federal source for science about the Earth, its natural and living resources, natural hazards, and the environment:

World Wide Web: http://www.usgs.gov

Telephone: 1-888-ASK-USGS

Suggested citation:

Friedel, M.J., and Finn, C., 2008, Hydrogeology of the Islamic Republic of Mauritania: U.S. Geological Survey, Open-File Report 2008-1136. 32 p.

Any use of trade, product, or firm names is for descriptive purposes only and does not imply endorsement by the U.S. Government.

Although this report is in the public domain, permission must be secured from the individual copyright owners to reproduce any copyrighted material contained within this report. 
Abstract

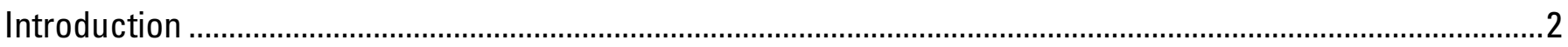

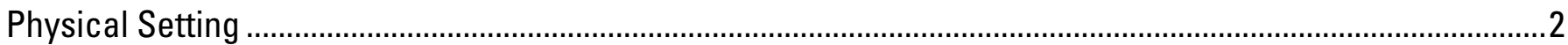

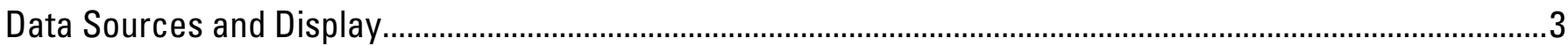

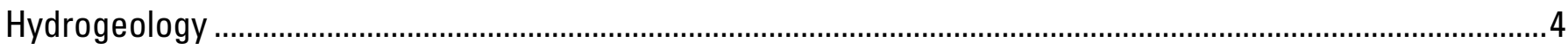

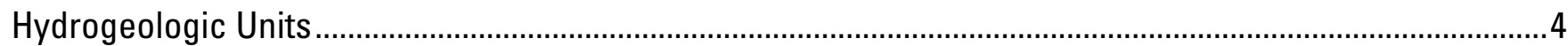

Coastal Deposits of Tertiary to Quaternary Ages (T0) ............................................................................

Sedimentary rocks of Jurassic Age (JS) ........................................................................................

Sedimentary Rocks of Carboniferous, Triassic-Cretaceous, and Quaternary Ages and Rhyolite of

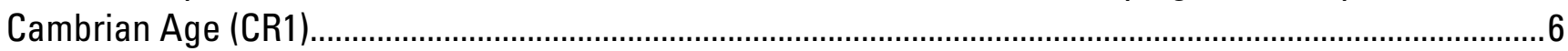

Sedimentary Rocks of Carboniferous and Triassic to Cretaceous Ages (CR2) ..........................................

Sedimentary Rocks of Silurian and Devonian Age (SD) ......................................................................

Sedimentary Rocks of Cambrian-Ordovician Age (415-540 Ma) (CO) .......................................................

Sedimentary Rocks of Neoproterozoic to Cambrian Age (N1) ..............................................................

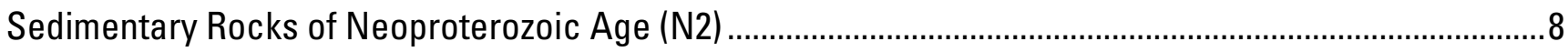

Sedimentary Rocks of Neoproterozoic (542-1000 Ma) age (N3) ………...................................................

Carbonate Rocks of Middle Mesoproterozoic (1250-1100 Ma) Age (PC1) ...............................................

Metasedimentary Rocks of Mesoproterozoic Age (PC2) ……...........................................................

Metavolcanic and Sedimentary Rocks of Mesoarchean (2800-3200 Ma) and Neoarchean Ages

(2500-2800 Ma), and Igneous, Metasedimentary, and Sedimentary Rocks of Paleoproterozoic Age

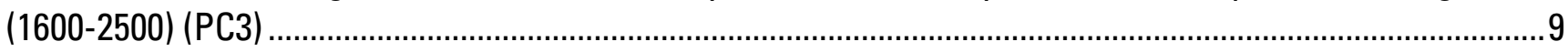

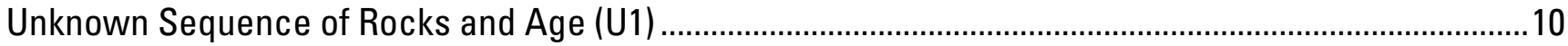

Hydrologic Properties ......................................................................................................................

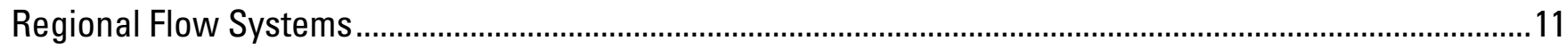

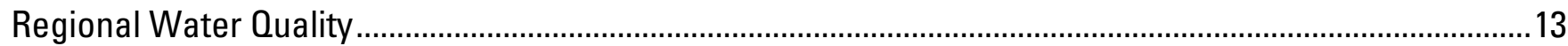

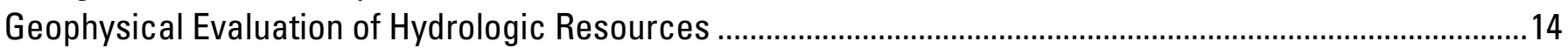

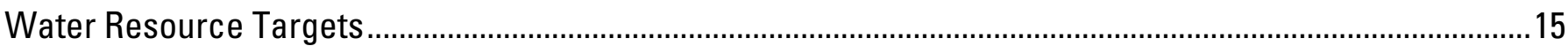

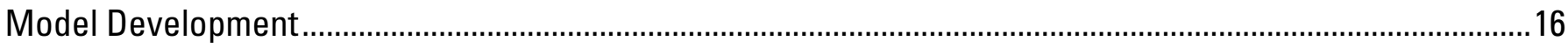

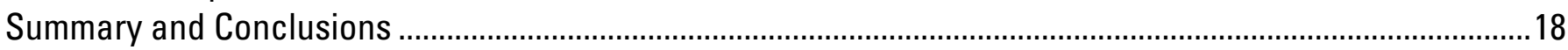

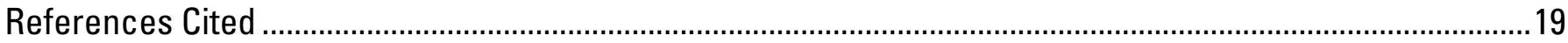




\section{Tables}

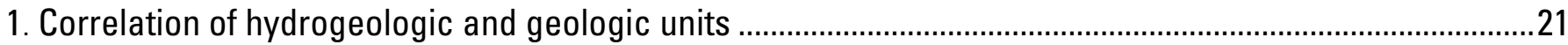

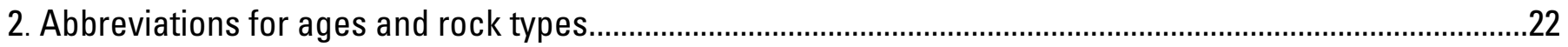

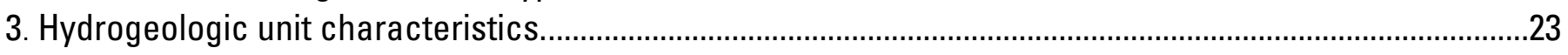

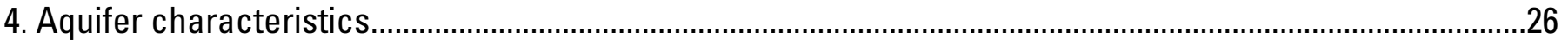

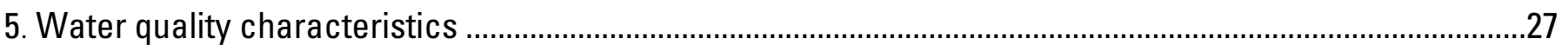

\section{Figures}

1. Color-shaded relief image of topography from SRTM and GTOPO data ......................................................28

2. Physical hydrogeologic map showing hydrogeologic units mapped across Mauritania ..............................29

3. Physical hydrogeologic map showing equipotentials of hydraulic head (potentiometric surface), ground- water flow paths, recharge and discharge zones, and flow conditions along country boundary. 30

4. Chemical hydrogeologic map showing the occurrence and distribution of water quality in Mauritania. ..31

5. Geophysical imaging: A.) Color-shaded relief image of gridded depth estimates. B.) Simple Bouguer gravity map of Mauritania. 


\section{Conversion Factors}

\section{Inch/Pound to SI}

\begin{tabular}{lll}
\hline Multiply & By & To obtain \\
\hline Length & & \\
\hline foot (ft) & 0.3048 & meter $(\mathrm{m})$ \\
mile (mi) & 1.609 & kilometer $(\mathrm{km})$ \\
yard (yd) & 0.9144 & meter $(\mathrm{m})$ \\
\hline Volume & & \\
\hline ounce, fluid $(\mathrm{fl} . \mathrm{oz})$ & 0.02957 & liter $(\mathrm{L})$ \\
gallon (gal) & 0.003785 & cubic meter $\left(\mathrm{m}^{3}\right)$ \\
cubic inch (in $\left.{ }^{3}\right)$ & 0.01639 & liter $(\mathrm{L})$ \\
cubic foot $\left(\mathrm{ft}^{3}\right)$ & 0.02832 & cubic meter $\left(\mathrm{m}^{3}\right)$ \\
\hline Flow rate & & \\
\hline foot per second (ft/s) & 0.3048 & meter per second $(\mathrm{m} / \mathrm{s})$ \\
cubic foot per second $\left(\mathrm{ft}^{3} / \mathrm{s}\right)$ & 0.02832 & cubic meter per second $\left(\mathrm{m}^{3} / \mathrm{s}\right)$ \\
\hline Mass & & \\
\hline ounce, avoirdupois $(\mathrm{oz})$ & 28.35 & gram $(\mathrm{g})$ \\
pound, avoirdupois $(\mathrm{lb})$ & 0.4536 & kilogram $(\mathrm{kg})$ \\
\hline
\end{tabular}

Temperature in degrees Fahrenheit $\left({ }^{\circ} \mathrm{F}\right)$ may be converted to degrees Celsius $\left({ }^{\circ} \mathrm{C}\right)$ as follows: ${ }^{\circ} \mathrm{C}=\left({ }^{\circ} \mathrm{F}-32\right) / 1.8$ 


\section{SI to Inch/Pound}

\begin{tabular}{lcl}
\hline Multiply & By & To obtain \\
\hline Length & & \\
\hline meter $(\mathrm{m})$ & 3.281 & foot $(\mathrm{ft})$ \\
kilometer $(\mathrm{km})$ & 0.6214 & mile $(\mathrm{mi})$ \\
meter $(\mathrm{m})$ & 1.094 & yard $(\mathrm{yd})$ \\
\hline Volume & & \\
\hline liter $(\mathrm{L})$ & 0.2642 & gallon $(\mathrm{gal})$ \\
cubic meter $\left(\mathrm{m}^{3}\right)$ & 264.2 & gallon $(\mathrm{gal})$ \\
liter $(\mathrm{L})$ & 61.02 & cubic inch $\left(\mathrm{in}^{3}\right)$ \\
cubic meter $\left(\mathrm{m}^{3}\right)$ & 35.31 & cubic foot $\left(\mathrm{ft}^{3}\right)$ \\
\hline Flow rate & & \\
\hline meter per second $(\mathrm{m} / \mathrm{s})$ & 3.281 & foot per second $(\mathrm{ft} / \mathrm{s})$ \\
cubic meter per second $\left(\mathrm{m}^{3} / \mathrm{s}\right)$ & 35.31 & cubic foot per second $\left(\mathrm{ft}^{3} / \mathrm{s}\right)$ \\
\hline Mass & & \\
\hline gram $(\mathrm{g})$ & 0.03527 & ounce, avoirdupois $(\mathrm{oz})$ \\
kilogram $(\mathrm{kg})$ & 2.205 & pound avoirdupois $(\mathrm{lb})$ \\
\hline
\end{tabular}

Temperature in degrees Celsius $\left({ }^{\circ} \mathrm{C}\right)$ may be converted to degrees Fahrenheit $\left({ }^{\circ} \mathrm{F}\right)$ as follows:

${ }^{\circ} \mathrm{F}=\left(1.8 \mathrm{x}^{\circ} \mathrm{C}\right)+32$ 


\title{
Hydrogeology of the Islamic Republic of Mauritania
}

\author{
By Michael J. Friedel and Carol Finn
}

Abstract

Hydrogeologic maps were constructed for the Islamic Republic of Mauritania. The ground-water flow system in the country can best be described as two interconnected regional systems: the porous Continental Terminal coastal system and the interior, fractured sedimentary Taoudeni Basin system. In these systems, ground-water flow occurs in fill deposits and carbonate, clastic, metasedimentary, and metavolcanic rocks. Based on an evaluation of the potentiometric surface, there are three areas of groundwater recharge in the Taoudeni Basin system. One region occurs in the northwest at the edge of the Shield, one occurs to the south overlying the Tillites, and one is centered at the city of Tidjikdja. In contrast to the flow system in the Taoudeni Basin, the potentiometric surfaces reveal two areas of discharge in the Continental Terminal system but no localized recharge areas; the recharge is more likely to be areal. In addition to these recharge and discharge areas, ground water flows across the country's borders. Specifically, ground water from the Atlantic Ocean flows into Mauritania, transporting dissolved sodium from the west as a salt water intrusion, whereas fresh ground water discharges from the east into Mali. To the north, there is a relatively low gradient with inflow of fresh water to Mauritania, whereas ground-water flow discharges to the Senegal River to the south.

A geographical information system (GIS) was used to digitize, manage, store, and analyze geologic data used to develop the hydrogeologic map. The data acquired for map development included existing digital GIS files, published maps, tabulated data in reports and public-access files, and the SIPPE2 Access database. Once in digital formats, regional geologic and hydrologic features were converted to a common coordinate system and combined into one map. The 42 regional geologic map units were then reclassified into 13 hydrogeologic units, each having considerable lateral extent and distinct hydrologic properties. Because the hydrologic properties of these units are also influenced by depth and degree of fracturing, the hydraulic conductivity values of these hydrogeologic units can range over many orders of magnitude. 


\section{Introduction}

The Islamic Republic of Mauritania is interested in developing tools and programs to help develop long-term and stable water supplies for agricultural, domestic, and mining use. Because of the many complicating and competing hydrogeologic and anthropogenic factors, the preferred approach is to perform quantitative analysis using numerical models. Previous numerical modeling studies recognized four national waterresource priorities: (1) protecting and expanding the ground-water supply for Nouakchott, the capital of Mauritania, (2) increasing mineral industry water supplies, (3) increasing rural water supplies, and (4) devising ground-water recharge strategies (British Geological Survey, 1996). Whereas various numerical ground-water flow and transport models are available, meaningful near- and long-term forecasts associated with these national priorities can only be conducted following proper model conceptualization, parameterization, and calibration. This report focuses on the regional ground-water flow characterization and the development of a hydrogeologic framework for future flow and transport modeling. This report describes the geometry, composition, and physical properties of the materials forming the natural hydrogeologic system, and provides information to develop numerical ground-water flow models. A series of digital hydrogeologic maps of Mauritania were produced to depict the surface expressions of the physical and chemical aspects of the hydrogeologic system. The selection of numerical modeling parameters is facilitated by data that accompany the hydrogeologic maps.

\section{Physical Setting}

The Islamic Republic of Mauritania is a country in northwestern Africa. It has the shape of an indented rectangle measuring about 1,500 km from north to south and about $1,000 \mathrm{~km}$ from east to west (fig. 1). It is bordered to the northwest by the Western Sahara, to the northeast by Algeria, to the east and southeast by Mali, and to the southwest by Senegal. Its Atlantic Ocean coastline, to the west, extends for $700 \mathrm{~km}$ from the delta of the Senegal River northward to the Cap Blanc Peninsula. The capital is Nouakchott.

Both land relief and drainage are influenced by the aridity that characterizes the greater part of Mauritania. The impression of immensity given by the landscape is reinforced by its relative flatness; the coastal plains are lower than $45 \mathrm{~m}$, whereas the 
higher plains of the interior vary from about 183 to $229 \mathrm{~m}$. The interior plains form a plateau of which the culminating heights, occurring at different levels, form many tablelands joined by long, gentle slopes of about $2^{\circ}$. The topography is relieved by vestiges of cliffs, by sloping plains that terminate in a steep cliffs or faulted scarps that may reach heights of as much as $274 \mathrm{~m}$, or by inselbergs (steep-sided residual hills), of which the highest is Mount Ijill at $915 \mathrm{~m}$.

\section{Data Sources and Display}

The creation of conceptual models and maps of geologically and hydrologically complex regions requires data management and quality controls. The identification, acquisition, and conversion of suitable data, and proper processing and analysis procedures for these data, were critical for successful characterization and conceptualization. The hydrogeologic data used in this study were largely retrieved from the SIPPE2 Access database (Dassargues, 2006). The queries used to retrieve and format data tables were developed as part of the Phase 1 inventory of hydrogeologic data (Friedel, 2008a). Examples of some database information used in this study included locations of cities, lithology (rock type), stratigraphy (geologic age), aquifer type (fractured versus porous) and nature (confinement), productivity, depth of production, hydrologic properties (transmissivity and hydraulic conductivity values), pump tests, static water level, and ground-water quality (dissolved bicarbonate, oxygen, nitrate, sodium, sulfate, and parameters such as electrical conductivity and temperature). These data tables were imported and projected using a geographic information system (GIS) to create layer files for combining and display. The GIS was used to manage, store, and analyze the digital data used to develop the hydrogeologic maps. Other data found in PRISM-II annexes 1-3 (Dassargues, 2006) included group and formation names by location, and the percentage range of productivity, which is the drilling success of encountering flow rates of water equal to or exceeding $1 \mathrm{~m}^{3} \mathrm{hr}^{-1}$ (success measurements are: Poor $-0-5 \%$, Fair $-5-45 \%$, Good $-45-65 \%$, Very good $-65-80 \%$, Excellent $-80 \%$ and above). The spatial productivity and information on roads and cities were also available and in some cases used as GIS layers. 


\section{Hydrogeology}

Conceptualization of a ground-water flow system requires the identification and assessment of various system elements that include: (1) definition of hydrogeologic units, (2) distribution of hydrologic properties of the units, (3) distribution and characteristics of geologic structures, and (4) identification and estimates of recharge, discharge, and boundary fluxes. Each of these system elements are described in more detail in the following sections.

\section{Hydrogeologic Units}

The rocks and deposits forming a hydrogeologic system are classified into a hydrogeologic unit, which is defined as a unit that has lateral extent and distinct hydrologic properties because of its geological and structural characteristics (Maxey, 1968). Because the overall study objective was to develop an understanding of the hydrogeology at a 1:1,000,000 scale, the hydrogeologic units were simplified. Although the major geological features were retained, many smaller geologic units were combined by generalizing both lithologic and hydrologic properties (the nature, type, productivity, and transmissivity) of the bedrock geology units. In applying these criteria, the 42 geologic units were grouped into 13 hydrogeologic units (tables 1 and 2). The abbreviations for the hydrogeologic units are arbitrary, being fashioned after group and/or formation age. The surface expression of these hydrogeologic units mapped across Mauritania, together with principal streams, lakes, annual rainfall, and cities, are shown in a physical hydrogeologic map (fig. 2). Numerous limitations are inherent in the creation of these digital map files. The maps are, at best, accurate only to the scale of the original digitized maps; in this case 1:500,000. In addition, the geologic units under the Sahara Dune field are interpreted based on surface expression, drillhole, and geophysical data, and information in various reports.

The following section describes the geologic and hydrologic characteristics of each hydrogeologic unit. A summary of these characteristics is provided in table 3 . Values of transmissivity and hydraulic conductivity are provided in table 4; however, there was no information available pertaining to storativity and porosity for any hydrogeologic units. 


\section{Coastal Deposits of Tertiary to Quaternary Ages (TO)}

The alluvial sediments of Tertiary to Quaternary ages (Paleocene, Eocene, Oligocene, and Miocene) are a heterogeneous mixture of coarse gravels, fine to shelly sand, sandstone, and caliche. Accordingly, this unit is likely to exhibit matrix (porous) flow that varies greatly over short distances, as does the degree of confinement (unconfined, semi-confined, and confined) and hydrologic properties (a transmissivity range from $3.50 \mathrm{E}-05$ to $2.57 \mathrm{E}-02 \mathrm{~m}^{2} \mathrm{hr}^{-1}$ ). These changes in hydraulic character, both laterally and vertically, reflect the abrupt changes in grain size, degree of sorting, and consolidation. The likelihood of flows exceeding $1 \mathrm{~m}^{3} \mathrm{hr}^{-1}$ is about $100 \%$.

The Continental Terminal Basin fill unit constitutes one of the two regional flow systems and is the most developed ground-water resource in Mauritania. The total fill ranges in thickness from tens of meters at the eastern edge (along the Mauritinides) to 4 $\mathrm{km}$ along Atlantic coast. Ground water flows into this basin from the interior Taoudeni Basin to the east, the Atlantic Ocean from the west, and the Senegal River from the south. Ground water leaves the basin primarily through evaporation and pumping at two well fields (pumping centers) near the center of the basin (fig. 3). Whereas recharge may occur across the basin, the amount will probably be restricted to locally focused recharge and limited regionally due to both the low average precipitation $(99 \mathrm{~mm})$ and the high average evaporation rate $(>4,100 \mathrm{~mm}$ ) (Friedel, 2008b). Unfortunately, the induced cones of depression at the pumping centers appear to have enhanced inland migration of salt water from the Atlantic Ocean, characterized by a plume that degrades the quality of water for distances of more than $100 \mathrm{~km}$ inland from the coast (fig. 4).

\section{Sedimentary rocks of Jurassic Age (JS)}

There is little information about this Jurassic sandstone other than it crops out in the interior Taoudeni Basin. The fact that ground water occurs in fractures associated with other rocks of like age suggests that similar behavior might occur in these rocks. Presently, there is no information available on the hydraulic characteristics of this unit or the degree to which exploitation of ground water has occurred. 


\section{Sedimentary Rocks of Carboniferous, Triassic-Cretaceous, and Quaternary Ages and Rhyolite of Cambrian Age (CR1)}

This sedimentary sequence is of Carboniferous, Triassic-Cretaceous, and Quaternary ages and is up to $2000 \mathrm{~m}$ thick in areas that overlie the Silurian-Devonian (SD) unit of the interior Taoudeni Basin. These sedimentary rocks include discontinuous dolorites (interpreted from aeromagnetic data) that overlie sandstone that are themselves underlain by shale. Cretaceous sandstones and Cambrian rhyolite rocks crop out at the center of the basin along the border between Mauritania and Mali. Transmissivity ranges for this unit include dolorite sills: $1 \mathrm{E}-8$ to $2.5 \mathrm{E}-2 \mathrm{~m}^{2} \mathrm{hr}^{-1}$, sandstone: $2 . \mathrm{E}-6$ to $2.8 \mathrm{E}-2 \mathrm{~m}^{2}$ $\mathrm{hr}^{-1}$, and shale: $1 \mathrm{E}-8$ to $1 \mathrm{E}-7 \mathrm{~m}^{2} \mathrm{hr}^{-1}$. Given the discontinuous nature of the dolorite sills and the fracturing of the shales, ground water is likely to occur in the sandstone and where other units are fractured. Because the sandstone is as permeable as the other rock types, flow is likely to occur along the axis of the sandstone, with some recharge occurring through leakage between discontinuous dolorite sills. Similarly, where the shale is fractured, the sandstone is likely to contribute water to the underlying rocks.

\section{Sedimentary Rocks of Carboniferous and Triassic to Cretaceous Ages (CR2)}

This sequence of rocks overlies the Silurian-Devonian (SD) unit of the Maqteir depression defined by seismic reflection data in the interior Taoudeni Basin (Islamic Republic of Mauritania, Ministry of Mines and Industry, 2007). There are no outcrops of rocks in this area, only dune sands associated with the Central Sahara Desert of Mauritania. Given the similarity of geophysical characteristics here to those associated with CR1, the hydraulic character is likely to be the same or similar. This character includes fracture-hosted ground-water flow through sandstones that are semi-confined above by dolorite sills and below by fractured shales that separate this flow from the deeper Tauodeni Basin system.

\section{Sedimentary Rocks of Silurian and Devonian Age (SD)}

This hydrogeologic unit consists of rocks from the l'Oued and Tenemouj Groups (geologic units: Ds, DSs, Ss) of Silurian and Devonian ages, respectively. The l'Oued 
Group hosts sandstone (including ferruginous sandstone), schist, argillite, and mudstone; the Tenemouj Group hosts sandstone, siltstone, and argillite. Outcrops of this hydrogeologic unit bound the Sahara Desert to the north and south, and overlie the Cambrian-Ordovician hydrogeologic unit at the central interior Maqteir Depression and the Taoudeni Basin Low, centered on the eastern border. Whereas the hydraulic characteristics of this fracture-dominated unit are unknown, the likelihood of flows greater than $1 \mathrm{~m}^{3} \mathrm{hr}^{-1}$ in the near-surface rocks is considered fair (5-45\%).

\section{Sedimentary Rocks of Cambrian-Ordovician Age (415-540 Ma) (CO)}

This hydrogeologic unit consists primarily of sedimentary rocks of Cambrian and Ordovician ages (geologic units: Os, OCs, Cs). Specific groups include: Njakane Abtelli and Tichit Groups (Ordovician superior); d'Oujeft (Cambrian-Ordovician superior), de la falaise d'Atar and Nouati Groups (Cambrian-Ordovician inferior); and the Teniagouri Group. Rocks in these Groups include graywacke, jasper, pelite, quartzite, and sandstone in the d'Oujeft Group; conglomerate, sandstone, and argillite in the Njakane Abtelli and Tichit Groups; graywacke, jasper, pelite, quartzite, and sandstone in the d'Oujeft Group; limestones in the de la falaise d'Atar Group; pelites and dolomites in the Nouati Group; and jasper, schist, sandstone, siltstone, and mudstone in the Teniagouri Group. Outcrops of this hydrogeologic unit run parallel to the Mauritinides (hydrogeologic unit PC2) and bound the Sahara Desert to the north and south. Over the central Taoudeni Basin, rocks of this unit overlie the Neo- and Meso-proterozoic (Infracambrian) rocks. The hydraulic characteristics of the permeable fracture-dominated unit include transmissivity values in the range of 4.4E-04 to $1.9 \mathrm{E}-03 \mathrm{~m}^{2} \mathrm{hr}^{-1}$. The likelihood of flows greater than $1 \mathrm{~m}^{3} \mathrm{hr}^{-1}$ in the near-surface rocks is considered very good (65-80\%), varying by lithology and Group: pelite (50\%) and sandstone (50\%) of the d'Oujeft Group; limestones (80\%) of the de la falaise d'Atar Group; and pelites (60\%) and dolomites (100\%) of the Nouati Group.

\section{Sedimentary Rocks of Neoproterozoic to Cambrian Age (N1)}

This hydrogeologic unit consist of tillites (geologic unit: $\mathrm{CNPt}$ ) of Neoproterozoic to Cambrian age. This fractured rock crops out as discontinuous islands within the PC2 
hydrogeologic unit and is adjacent to the hydrogeologic unit of greatest productivity (N2) to the south. This unit crops out south of the interior Maqteir depression. The hydraulic properties of this unit are considered impermeable, but its discontinuous nature may give rise to semi-confined conditions with leakage between overlying and underlying units.

\section{Sedimentary Rocks of Neoproterozoic Age (N2)}

This hydrogeologic unit consists of mostly pelite and dolorite sills (rock unit: CNPs), with minor sandstone. This fractured rock unit crops out in the south Tauodenin Basin and overlies the region subject to syntectonic uplift. Where drilled, this region exhibits good productivity in the 45-65\% range, with permeable, fracture-dominated characteristics that include transmissivity values in the range of $1.5 \mathrm{E}-06$ to $9.3 \mathrm{E}-04$ $\mathrm{m}^{2} \mathrm{hr}^{-1}$. The likelihood of flows greater than $1 \mathrm{~m}^{3} \mathrm{hr}^{-1}$ in the near-surface rocks is considered very good (65-80\%), but much of this unit has not been explored because of the overlying dune sands.

\section{Sedimentary Rocks of Neoproterozoic (542-1000 Ma) age (N3)}

This hydrogeologic unit consists primarily of sandstone and pelites (geologic unit: NPs) of Neoproterozoic to Cambrian ages. This fractured rock unit crops out parallel to the Reguibat Shield in the north and as a rectangular region at the center of N2 adjacent to the Senegal River. The hydraulic characteristics of the permeable fracture-dominated unit include transmissivity values in the range of $2.3 \mathrm{E}-6$ to $2.8 \mathrm{E}-2 \mathrm{~m}^{2} \mathrm{hr}^{-1}$. The likelihood of flows greater than $1 \mathrm{~m}^{3} \mathrm{hr}^{-1}$ in the near surface of this hydrogeologic unit is about $80 \%$ (excellent).

\section{Carbonate Rocks of Middle Mesoproterozoic (1250-1100 Ma) Age (PC1)}

This hydrogeologic unit consist primarily of limestone and dolomite (geologic unit: MP2c) of Neoproterozoic to Cambrian ages. This karst rock unit only crops out in the north, parallel to the Reguibat Shield. The likelihood of flows greater than $1 \mathrm{~m}^{3} \mathrm{hr}^{-1}$ in the near surface of this hydrogeologic unit is about $80 \%$ (excellent), but the hydraulic properties of this unit are unknown. 


\section{Metasedimentary Rocks of Mesoproterozoic Age (PC2)}

This fractured rock hydrogeologic unit, often referred to as the Mauritinides, consists of metasedimentary, metabasalt, metarhyolite, and mafic intrusive rocks of Mesoproterozoic age (rock units: MP1s, MP2s, NPPPm, NPPPms, NPPPmv, NPPPx, NPm, and CNPs). The general hydraulic character of this unit is an aquitard or hydrologic barrier; however, local hydraulic conditions in some rock types such as schist promote fracture flow. The hydraulic characteristics of the permeable, fracture-dominated unit include transmissivity values in the range of $2.8 \mathrm{E}-04$ to $1.2 \mathrm{E}-03 \mathrm{~m}^{2} \mathrm{hr}^{-1}$. The likelihood of flows greater that $1 \mathrm{~m}^{3} \mathrm{hr}^{-1}$ is about 45-65\%, but only locally and in highly fractured regions. This hydrologic unit impedes flow over a distance of about $150 \mathrm{~km}$ near its center, forcing ground water to flow north or south around it.

\section{Metavolcanic and Sedimentary Rocks of Mesoarchean (2800-3200 Ma) and Neoarchean Ages (2500-2800 Ma), and Igneous, Metasedimentary, and Sedimentary Rocks of Paleoproterozoic Age (1600-2500) (PC3)}

This hydrogeologic unit, called the Reguibat Shield, consists of metavolcanic and sedimentary rocks of Mesoarchean (2800-3200 Ma) and Neoarchean ages (2500-2800 $\mathrm{Ma}$ ), and andesite, gneiss, granitoid, metasedimentary, and undifferentiated sedimentary rocks of Paleoproterozoic age (1600-2500 Ma) (rock units: MAmv, MAs, MAn, PPi, PPg, PP1n, PPs, PPms, PPr, PPa, PP1g, PP2g, and PP3g). Despite the intense fracturing of this unit, most fractures appear to be disconnected between individual rock units, resulting in poor production of about $0-5 \%$. Where the unit is productive, the transmissivity values range from $2.8 \mathrm{E}-4$ to $1.2 \mathrm{E}-3 \mathrm{~m}^{2} \mathrm{hr}^{-1}$. In most areas there is no productivity, probably due to hydraulic properties on the order of $1 \mathrm{E}-8 \mathrm{~m}^{2} \mathrm{hr}^{-1}$. For this reason, this hydrogeologic unit may be considered essentially a confining unit that forms the base of the central interior Maqteir Depression and the Taoudeni Basin centered on the eastern border. 


\section{Unknown Sequence of Rocks and Age (U1)}

This unknown sequence of rocks may overlie at least part of the Devonian SD aquifer in the southeastern Sahara Desert. There are no outcrops of rocks in this area, only dune sands. There is no information available on the hydraulic characteristics of this unit.

\section{Hydrologic Properties}

A literature search on the hydrologic properties of rocks in Mauritania was conducted as part of PRISM-II (Dassargues, 2006), and revealed numerous site-specific, in-situ field tests (Blanchot, 1975) that measured hydrologic properties ranging over several orders of magnitude. For example, hydraulic conductivity ranges between 1.0E-06 $\mathrm{m} \mathrm{hr}^{-1}$ for schist and $5.8 \mathrm{E}-03 \mathrm{~m} \mathrm{hr}^{-1}$ for shelly sand. Similarly, values of transmissivity range over 4 orders of magnitude, with a minimum of $1.50 \mathrm{E}-06 \mathrm{~m}^{2} \mathrm{hr}^{-1}$ for dolorites and pelites and a maximum of $6.94 \mathrm{E}-02 \mathrm{~m}^{2} \mathrm{hr}^{-1}$ for shelly sand. The hydraulic characteristics of many geologic rock units is unknown and therefore warrant further study. A summary of available conductivity and transmissivity values for various rock types is presented in table 4. The in-situ coastal and interior field hydrologic tests also indicated differences in hydraulic characteristics. In the coastal basin tests, the results were characteristic of an equivalent porous media, whereas results for the interior basin were characteristic of fractured rock hydrology. Other hydrologic properties such as porosity and storativity were not listed for any rock types (Friedel, 2008a).

Recent hydrogeologic investigations in Mauritania lack any quantitative assessment of the hydraulic role of faults. As a result, information is unavailable on the influence of regional fault zones on ground-water flow patterns. Because anecdotal information suggests that the regional ground-water flow system may be influenced by deep ground-water flow paths, another aspect not previously studied but worth considering is the effect of depth on hydrologic properties. For example, one hypothesis is the likelihood of increased jointing or fracturing near the surface, caused by stress released from erosional unloading and weathering, that may yield larger hydraulic 
conductivity values for rocks at shallow depths. Because most well tests are only measured at shallow depths $(<150 \mathrm{~m})$, other hydrologic property data were evaluated from similar arid systems elsewhere, such as the Death Valley, California, regional aquifer (Bedinger and others, 1989b). The available data, along with anecdotal information, were used to reach the following conclusions:

- Weathering and fractures (due to release of confining pressures by erosional unloading) probably are not significant at depths below $300 \mathrm{~m}$.

- At increased depths, overburden pressures tend to decrease the apertures of joints or fractures and the size of pores, and therefore porosity and intrinsic permeability tend to decrease.

- $\quad$ Surface faults and fractures are good indicators of the orientation and position of permeable zones at depths up to $1,000 \mathrm{~m}$.

- In some areas, solution-type voids and relict cavernous features may withstand overburden pressures in crystalline carbonate rocks, allowing these features to remain open at depths up to 2,000 to $3,000 \mathrm{~m}$.

Large, regional crustal fault zones are good indicators of areas of significantly increased hydraulic conductivity at great depths. The regional hydraulic conductivity resulting from fractures is dependent not only on the presence of open fractures, but also on the rock type, fracture orientation, and regional history of tectonic stress.

\section{Regional Flow Systems}

The characterization of ground-water flow through Mauritania was based on evaluating flow paths drawn perpendicular to equipotential lines of hydraulic head. The 978 values of hydraulic head were computed by subtracting the observed water levels from co-located elevations. Whereas the observed water levels obtained from the SIPPE2 database (Friedel, 2008a) were given specific coordinates, the location of elevation values were interpolated from a digital elevation model with a $90-\mathrm{m}$ resolution. These estimated values of head were plotted and analyzed using the GIS to look for spatial statistical relations using a variogram. The lack of any obvious spatial statistical relation among head values ruled out the development of a variogram and determination of a 
kriging estimation variance. For this reason, alternative interpolators were evaluated. The radial basis function proved to be an unbiased interpolator, as shown by a weighted mean of residuals on the order of $10^{-2}$ and by predictions that match the observations.

Flow paths were drawn orthogonal to the head contours to identify ground-water recharge and discharge areas, and flow boundary conditions (such as areas of no flow, ground-water divides, or hydraulic barriers). These hydrogeologic features are plotted on the second physical hydrogeologic map (fig. 3). The ground-water flow system in Mauritania can best be described as two interconnected regional systems: a coastal porous basin (called the Continental Terminal Basin) and an interior, fractured sedimentary basin (called the Taoudeni Basin).

Ground water from five separate recharge areas flows out of the Taoudeni Basin in three general directions: east toward Mali, west toward the Continental Terminal Basin, and south toward the Senegal River. Ground water flows into the Continental Terminal Basin from the Atlantic Ocean and from two interior Taoudeni Basin recharge areas. One of these two recharge areas is located northeast of Atar at the northwestern edge of the Réguibat Shield (Hydrogeologic unit PC1), and the other is centered at the city of Tidjikdja (Hydrogeologic unit CO). The transfer of ground water from the Taoudeni Basin to the Continental Terminal Basin occurs along two primary flow paths that deflect around a 150-km-long hydrologic barrier and trend northwest-southeast along the axis of the Mauritinides (Hydrogeologic unit PC2) east of Akjoujt. Some ground water from the second recharge area flows northwest, then turns south near another hydrologic barrier. This northwest-southeast-trending barrier is about $200 \mathrm{~km}$ long and coincides with the structural high of a Silurian-Devonian ridge separating the Maqteir Depression from the Taoudeni Basin Low that straddles the border between Mauritania and Mali.

A third ground-water recharge area in the Taoudeni Basin is in the south, overlying the Tillites (Hydrogeologic units N1 and N2) between the cities of Kifa and 'Ayoun el Atrous. Ground water here discharges south to the Senegal River. The fourth and fifth recharge areas contribute water to the Taoudeni Basin Low and eventually to Mali: one is in the center of the country in the Sahara Desert and another is in its southeastern corner. 
Ground water is also being withdrawn at two water-supply well fields that appear as discharge areas: $100 \mathrm{~km}$ east of Nouakchott and $165 \mathrm{~km}$ southeast of Nouakchott. During this study, there were no pumping records provided for any wells in Mauritania.

\section{Regional Water Quality}

A chemical hydrogeologic map was constructed to illustrate the occurrence and distribution of degrees of water quality in Mauritania (fig. 4). Selected dissolved waterquality indicators and basic aqueous parameters were analyzed for their occurrence and distribution across the country. The dissolved chemical elements included bicarbonate, nitrate, and sulfate, and the aqueous parameters evaluated included electrical conductivity (salinity) and dissolved oxygen. A summary table of statistics is provided for each mapped element and aqueous parameter (table 4). The data are limited in number and are spatially biased, with the majority of samples taken from the Continental Terminal Basin and southern portions of exposed hydrogeologic units in the Taoudeni Basin.

An important element of this study was to identify potential regions of suitable water quality for use as public water supplies. Toward that end, the occurrence and distribution of salinity in Mauritanian ground water was mapped. Because the majority of the 796 ground-water monitoring sites measured electrical conductivity (EC) but not total dissolved solids (TDS), these EC values needed to be converted to an equivalent value of salinity using a regression relation. The relation used to convert EC to TDS was based on application of the regression process to fit an equation to $128 \mathrm{EC}$ measurements that were concurrently sampled and analyzed for TDS. After converting the values of EC to TDS, they were plotted and contoured, revealing a prominent salt water intrusion from the Atlantic Ocean into the coastal basin. A gradient of salinity occurs inland over a distance of about $100 \mathrm{~km}$ and spans a range of categories: fresh $\left(<1,000 \mathrm{mg} \mathrm{L}^{-1}\right)$, brackish $(1,000-$ $\left.5,000 \mathrm{mg} \mathrm{L}^{-1}\right)$, highly brackish (5,000-15,000 $\left.\mathrm{mg} \mathrm{L}^{-1}\right)$, saline $\left(15,000-30,000 \mathrm{mg} \mathrm{L}^{-1}\right)$, sea water (30,000-40,000 $\left.\mathrm{mg} \mathrm{L}^{-1}\right)$ and brine (40,000-300,000 $\left.\mathrm{mg} \mathrm{L}^{-1}\right)$. Two other smaller areas also reveal elevated salinity concentrations. These areas of brackish water are in the south-central Taoudeni Basin (hydrogeologic unit PC2) just west of Kipa, and between Kipa and 'Ayoun el Atrous. The elevated salinity contours appear elongated in a northsouth trend that coincides with flow paths that discharge into the Senegal River. Apart from these three areas, the majority of Mauritania's ground water is fresh. 


\section{Geophysical Evaluation of Hydrologic Resources}

Basins must have sufficient volume, porosity, and good-quality water to be worthy of exploitation. A recent inventory of hydrogeologic data in Mauritania revealed a lack of information about thicknesses of rock units (Friedel, 2008a). Geophysical data are used here to determine the extent of hydrogeologic units and confirm interpreted barriers to ground-water flow.

Aeromagnetic data were recently acquired (ref, 2006) and merged with older United Nations (UN) data over the coastal Continental Terminal and interior Taoudeni Basins. Depth estimates from these data were calculated using the extended Euler method (Phillips, 2002) with a structural index of 0 (magnetic contact) and a window of 7 (fig. 5a). While all results were in general agreement, the estimated depths determined where only the more widely spaced UN data were available over the Coastal basin seem to be about $1 \mathrm{~km}$ deeper than those estimated using the newer data. Hence, there is some uncertainty in the true depth estimates for the Continental Terminal Basin. Depth estimates calculated from other methods over the Coastal basin made using these aeromagnetic data suggest depths of about $0.1 \mathrm{~km}$ along its eastern edge (adjacent to hydrogeologic unit PC2, the Mauritinides), about 2-3 km at its center, and about 3-4 km along the western Atlantic coast.

In the Taoudeni Basin, the magnetic depth estimates reveal that depth increases rapidly from about $500 \mathrm{~m}$ to $1 \mathrm{~km}$ at the basin's edge to greater than $2 \mathrm{~km}$ at about $25 \mathrm{~km}$ from the edge toward the basin's center. Estimates of the greatest depths are about $6 \mathrm{~km}$ in areas not covered by the dolorite sills. The calculated minimum depth to magnetic basement at the center of the basin is about $3 \mathrm{~km}$, which was confirmed during drilling of the Abolag-1 well (Islamic Republic of Mauritania, Ministry of Mines and Industry, 2007). Processed seismic reflection data from that report indicates that the Taoudeni Basin reaches a maximum depth of about $6 \mathrm{~km}$ at the central eastern border of Mauritania. In contrast, the report shows depths to the Jurassic dolorite sills that are about 0.5 to $1.5 \mathrm{~km}$, in reasonable agreement with the seismically determined thickness of the Devonian section over which the sills lie. These seismic and drilling data also reveal a Devonian-Silurian ridge between the Maqteir Depression and Taoudeni Basin Low, which confirms the $200 \mathrm{~km}$ northwest-southeast-trending hydrologic barrier previously 
described. Magnetic data over the southern region indicates the presence of sedimentary rocks and sills underlain by sedimentary rocks that could provide water.

Proprietary gravity data were recently obtained from a French agency (M. Albouy, written commun, 2006) to identify and evaluate the two major Mauritanian ground-water basins (fig. 5b). Several approximately 40-km-wide, linear, 20-35 mGal gravity lows occur over the coastal basin. These gravity lows correspond to the location of pumping centers in the basin and are interpreted as less-dense sediments. Gravity lows over the Réguibat Shield indicate density variations within the Precambrian terrane and not ground-water basins. Several linear northeast-trending gravity lows over the southwestern edge of the Taoudeni Basin in the Mauritinides are co-oriented with magnetic lows and are interpreted to be caused by Precambrian basement (Roussel and Lesquer, 1991). A positive gravity anomaly in the north-central Mauritinide Belt reveals that the high-density Precambrian basement is shallow here. This supports the previously interpreted location of a hydrologic barrier that restricts regional flow between basins. The persistence of the gravity high along the Mauritinide Belt to the north and south coincides with highly fractured regions, suggesting preferential fracture flow of limited depth from interior to coastal basin. The other prominent gravity high in the Continental Terminal Basin along the Atlantic Coast coincides with the center of the salt water plume migrating toward the primary pumping center (fig. 3). The gravity high is not likely caused by low-density salt water but rather by higher-density gravels and/or basement rocks. Further study of these relations is required to pinpoint the gravity source more accurately.

\section{Water Resource Targets}

This section identifies new water-resource targets for potential development in support of mining and public supply needs in Mauritania. The selection of these targets is based on a combination of historical drilling productivity, geophysical interpretations including degree of fracturing, the absence of subsurface dikes, and the quality of water.

1. Sedimentary rocks of Cambrian-Ordovician age (CO) 
The combined regional gravity low associated with fracturing of this unit and the lack of dikes indicated by the aeromagnetic map support this unit as a highly valued water-resource target. To the north, the gravity values increase, possibly indicating less intensity in fracturing; however, the depth of this unit increases northward, enhancing the total potential volume to be explored. This region remains comparatively unexploited and therefore may prove beneficial to the mining industry.

\section{Sedimentary rocks of Neoproterozoic age (N3)}

Whereas this hydrogeologic unit demonstrated the greatest productivity of all hydrogeologic units, little exploration has occurred in the north, possibly because of its remoteness. This unit appears to be a good target for water-resource exploitation because the hydraulic properties are among the greatest for fractured rock units of the Taoudeni Basin. The two prominent gravity lows in the south suggest relatively low-density rocks that are likely due to intense fracturing and/or local faulting; however, the estimated thickness is comparatively thin and the unit has intermediate resources compared to other hydrologic units.

\section{Carbonate rocks of middle Mesoproterozoic age (PC1)}

This hydrologic unit remains largely unexplored, probably because much of it lies below the dune sands. The dune sands are comparatively thin (0 to $100 \mathrm{~m}$ ) in areas adjacent to the shield, and production in the uncovered southern outcrop is about $80 \%$, making this a good target for water resource exploration.

\section{Model Development}

The future development of a ground-water flow and transport model will require several steps: conceptualization, parameterization, calibration, validation, and predictive analysis. In the present study, the conceptual development of a model for the coastal and interior ground-water basins is possible by reviewing the spatial extent of units in the hydrogeologic map. Depth estimates for various units can be obtained from the interpreted geophysical and borehole data. Model parameterization requires defining a 
numerical grid that accounts for spatial distribution of parameter values. Flow modeling requires assigned values of hydraulic properties (transmissivity or hydraulic conductivity, and storativity). The solute transport model requires values of transport properties (porosity, distribution coefficients, dispersivities, and density). For these flow and transport parameter values, one suggestion is to generate a random spatial distribution for each known property, assuming a log-normal distribution to reflect the random and heterogeneous nature of fractured-rock production rates. A statistical description for some hydraulic property values are found in tables 3 and 4. Other hydraulic and transport property values are not known and will have to be determined from additional field tests or available literature.

Boundary conditions must be applied to grid cells so that the dependent variables change from static equilibrium. Some common spatial and temporal boundary conditions include recharge that is assigned to the uppermost model layer, constant head and/or flux along vertical boundaries, and pumping rates in wells. In Mauritania, a first-order approximation for recharge might reflect an annual negative value because evaporation is 1-2 orders of magnitude greater than precipitation. In actuality, however, some locations show regionally focused recharge in the Taoudeni Basin. Likewise, not all focused recharge may be evident because of the hydrogeologic map scale and assumptions made in its development. In both cases, however, further study is necessary to confirm the location, magnitude, and importance of focused recharge. The approximate vertical boundary flux also must be computed.

For a steady-state ground-water flow model, approximate values for vertical boundary flux conditions may be computed from the equipotential surface (see the hydrogeologic map) and the geometric mean of layer transmissivity values along that boundary. At the scale of the hydrogeologic map, only two discharge locations in the Coastal Terminal Flow System are evident. These discharge locations must be specified in the model, and the annual pumping rates need to be determined from existing records and assigned as internal boundary conditions.

Following conceptualization and parameterization, the model needs to be calibrated and validated, and its prediction uncertainty analyzed. During calibration of the steady-state model, important dependent variables must be replicated to include the regional hydraulic head fields, the internal and boundary fluxes, and the water levels in 
assigned wells. Because optimally estimated parameter values are nonunique, the predictions also will be nonunique and therefore stochastic; that is, the prediction will be one of many, bounded by an upper and lower range of predictive uncertainty. For details of these modeling processes, the reader is referred to an overview by Friedel (2008b).

\section{Summary and Conclusions}

The regional physical and chemical hydrogeology of Mauritania was evaluated and presented as a series of maps for future use in ground-water flow and transport modeling. To facilitate model development, the following items need to be considered:

1. Combining hydrologically similar rock units facilitated the construction of a hydrogeologic map. Important regional features include streams, lakes, equipotential surface, and flow paths.

2. Mapping of ground-water flow paths revealed 4 recharge areas in the interior Taoudeni Basin, 2 discharge areas in the coastal Continental Terminal Basin, interbasin transfer of ground water, and ground-water flow across the Mauritanian border.

3. Mapping of salinity revealed that most of Mauritania consists of fresh water, but salt water intrusion occurs along the Atlantic Coast.

4. Mapping estimated depths of the coastal and interior basins was possible using aeromagnetic data.

5. Mapping gravity anomalies provided confirmation of barriers to ground-water flow in both the coastal and interior basins.

6. Information on the timing and pumping rates of ground water in the two primary discharge areas of the Continental Terminal Basin are necessary to apply as model boundary conditions.

7. Information on water levels and dates in the two primary discharge areas of the Continental Terminal Basin is required for the model calibration process. 


\section{References Cited}

Bedinger, M.A., Sargent, K.A., and Langer, W.H., 1989, Studies of geology and hydrology in the Basin and Range Province, southwestern United States, for isolation of high-level radioactive waste-characterization of the Death Valley region, Nevada, and California: U.S. Geological Survey Professional Paper 1370, B: 43 p.

Blanchot, A., 1975, Plan minéral de la République Islamique de Mauritanie: BRGM, 564 p. [R7500100.PDF].

British Geological Survey, 1996, First Projet de renforcement Institutionnel du Secteur Minier (PRISM-1), 189 p.

Dassargues, A., 2006, PRISM II: Second project of strengthening of the institutions of the Mining Sector - An evaluation of the hydrogeologic studies: Presentation at PRISM II meeting, Sabah Hotel, Nouakchott, Mauritania.

Friedel, M.J., 2008a, in-review Inventory and review of existing PRISM hydrogeologic data for the Islamic Republic of Mauritania, Africa: U.S. Geological Survey Open File Report, $2008-1138$, xx p.

Friedel, M.J., 2008b, in-review, Hydrologic model calibration strategy for the Islamic Republic of Mauritania, Africa: U.S. Geological Survey Open File Report, xx -xxxx, $28 \mathrm{p}$.

Islamic Republic of Mauritania, Ministry of Mines and Industry, 2007, Hydrostratigraphic traps and reservoirs: http://www.mmi.mr/english/hydrocarbons/taoudeni.html (last date reviewed: August 2, 2007).

Maxey, G.B., 1968, Hydrogeology of desert basins: Ground Water, v. 6, no. 5, p. 10-22. 
Phillips, J.D., 2002, Two-step processing for 3D magnetic source locations and structural indices using extended Euler or analytic signal methods: Society of Exploration Geophysicists, 2002, Technical Program Expanded Abstracts, 4 p.

Roussel, J., and Lesquer, A., 1991, Geophysics and the crustal structure of west Africa, in Dallmeyer, R.D., and Lecorche, J.P., eds., The West African Orogens and CircumAtlantic Correlatives: Berlin, Springer-Verlag, p. 9-28. 
Table 1. Correlation of hydrogeologic and geologic units.

\section{Hydrogeologic unit}

Coastal deposits of Quaternary-Tertiary ages (TQ)

Sandstone of Jurassic age (JS)

Sedimentary rocks of Carboniferous, Cretaceous, and

Quaternary ages and rhyolite of Cambrian age (CR1)

Unknown sequence of rocks of (CR2)

Sedimentary rocks of Silurian and Devonian ages (SD)

Sedimentary rocks of Cambrian and Ordovician ages $(\mathrm{CO})$

Tillites of Neoproterozoic to Cambian ages (N1)

Sedimentary rocks of Neoproterozoic age (N2)

Sedimentary rocks of Neoproterozoic age (N3)

Carbonate rocks of middle Mesoproterozic age (PC1)

Sedimentary rocks of Mesoproterozoic age; metasedimentary, metabasalt, metarhyolite, and mafic intrusive rocks of Neoproterozoic age (PC2)

Metavolcanic and undifferentiated sedimentary rocks of Mesoarchean and Neoarchean ages; andesite, gneiss,

granitoid, metasedimentary, and undifferentiated sedimentary rocks of Paleoproterozoic age (PC3)

Unknown sequence of rocks of (U1)

Unknown sequence of rocks of (U2)

\section{Geologic unit}

CR, JTr, Ks, Qh

$\mathrm{CR}, \mathrm{JTr}$

Ds, DSs, Ss

Os, OCs, Cs

CNPt

CNPs

NPs

MP2c

MP1s, MP2s, NPPPm, NPPPms, NPPPmv, NPPPx, NPg, NPm

MAmv, MAs, MAn, PPa, PPg, PPi, PPms, PPr, PPs, PP1g, PP1n, PP2g, and PP3g

Unknown

Unknown 
Table 2. Abbreviations for ages and rock types.

\begin{tabular}{|c|c|c|c|}
\hline \multicolumn{2}{|r|}{ Ages } & \multicolumn{2}{|c|}{ Rock Types } \\
\hline $\mathrm{Q}$ & Quaternary & $\mathrm{A}$ & alkalic intrusive rocks \\
\hline $\mathrm{T}$ & Tertiary & G & granitoids \\
\hline K & Cretaceous & $\mathrm{P}$ & pegmatite \\
\hline $\mathrm{J}$ & Jurassic & M & mafic intrusive rocks \\
\hline $\mathrm{JTr}$ & Jurassic to Triassic & $\mathrm{U}$ & ultramafic rocks \\
\hline CR & Carboniferous & & \\
\hline $\mathrm{D}$ & Devonian & $\mathrm{V}$ & basalt etc. \\
\hline DS & Devonian to Silurian & $\mathrm{Mv}$ & metabasalt \\
\hline S & Silurian & i & andesite \\
\hline $\mathrm{O}$ & Ordovician & $\mathrm{mi}$ & meta-andesite \\
\hline $\mathrm{OE}$ & Ordovician to Cambrian & $\mathrm{r}$ & rhyolite \\
\hline$\epsilon$ & Cambrian & $\mathrm{mr}$ & metarhyolite \\
\hline NPE & Neoproterozoic to Cambrian & & \\
\hline NP & Neoproterozoic (542-1000 Ma) & $\mathrm{n}$ & gneiss \\
\hline NPPP & Neoproterozoic to Paleoproterozoic & $\mathrm{y}$ & mylonite \\
\hline \multicolumn{2}{|c|}{ MP1 = older Mesoproterozoic (1600-1300) } & $\mathrm{x}$ & melange \\
\hline \multicolumn{2}{|c|}{ MP2 $=$ middle Mesoproterozoic $(1250-1100)$} & & \\
\hline PP & Paleoproterozoic (1600-2500 Ma) & $\mathrm{s}$ & sedimentary rocks, undivided \\
\hline & PP1 = between 2150 and $2100 \mathrm{Ma}$ & $\mathrm{ms}$ & metasedimentary rocks \\
\hline & PP2 = between 2050 and $2100 \mathrm{Ma}$ & $\mathrm{c}$ & carbonate rocks \\
\hline & PP3 = between 1995 and $2050 \mathrm{Ma}$ & $\mathrm{f}$ & iron formation \\
\hline $\mathrm{P}$ & Proterozoic & $\mathrm{t}$ & tillite \\
\hline NA & Neoarchean (2500-2800 Ma) & $\mathrm{h}$ & caliche (hamada) \\
\hline MA & Mesoarchean (2800-3200 Ma) & $\mathrm{d}$ & dune sand \\
\hline
\end{tabular}


Table 3. Hydrogeologic unit characteristics.

\begin{tabular}{|c|c|c|c|c|c|c|c|c|}
\hline \multirow[b]{2}{*}{ Hydrogeologic unit ${ }^{1}$} & \multirow{2}{*}{$\begin{array}{l}\text { Formation } \\
\text { lithologies }^{2}\end{array}$} & \multirow[b]{2}{*}{ Basin } & \multirow[b]{2}{*}{ Nature $^{3}$} & \multirow{2}{*}{$\begin{array}{c}\text { Production }^{5} \\
\%\end{array}$} & \multirow[b]{2}{*}{ Type } & \multicolumn{3}{|c|}{ Transmissivity ${ }^{6}\left(\mathrm{~m}^{2} \mathrm{hr}^{-1}\right)$} \\
\hline & & & & & & Minimum & Maximum & Median \\
\hline $\begin{array}{l}\text { Coastal sedimentary } \\
\text { deposits of Quaternary- } \\
\text { Tertiary ages (TQ) }\end{array}$ & $\begin{array}{l}\text { Continental } \\
\text { terminal } \\
\text { sandstones, sand, } \\
\text { gravel, caliche }\end{array}$ & Coastal & Porous & 100 & Aquifer & $3.5 \mathrm{E}-05$ & 2.6E-02 & $3.0 \mathrm{E}-03$ \\
\hline $\begin{array}{l}\text { Sedimentary rock of } \\
\text { Jurassic age (JS) }\end{array}$ & Sandstone & Interior & Fractured & Unknown & Unknown & Unknown & Unknown & Unknown \\
\hline \multirow{3}{*}{$\begin{array}{l}\text { Sedimentary sequence of } \\
\text { rocks of Carboniferous, } \\
\text { Triassic-Cretaceous, and } \\
\text { Quaternary ages and } \\
\text { rhyolite of Cambrian age } \\
\text { (CR1) }\end{array}$} & Dolorite sills ${ }^{\#}$ & Interior & Fractured & Unknown & Aquitard & 1.0E-08 & $2.5 \mathrm{E}-02$ & $5.2 \mathrm{E}-06$ \\
\hline & Sandstones $^{\#}$ & Interior & Fractured & Unknown & Aquifer & 2.3E-06 & 2.8E-02 & $1.2 \mathrm{E}-04$ \\
\hline & Shales & Interior & Fractured & Unknown & Aquitard & $1.0 \mathrm{E}-08$ & $1.0 \mathrm{E}-07$ & 5.5E-08 \\
\hline \multirow{3}{*}{$\begin{array}{l}\text { Sedimentary sequence of } \\
\text { rocks of Carboniferous, } \\
\text { Triassic-Cretaceous ages } \\
\text { (CR2) }\end{array}$} & Dolorite sills ${ }^{\#}$ & Interior & Fractured & Unknown & Aquitard & $1.9 \mathrm{E}-06$ & 2.5E-02 & $5.2 \mathrm{E}-06$ \\
\hline & Sandstones $^{\#}$ & Interior & Fractured & Unknown & Aquifer & $2.3 \mathrm{E}-06$ & 2.8E-02 & $1.2 \mathrm{E}-04$ \\
\hline & Shales & Interior & Fractured & Unknown & Aquitard & $1.0 \mathrm{E}-08$ & 1.0E-07 & $5.5 \mathrm{E}-08$ \\
\hline $\begin{array}{l}\text { Sedimentary rocks of } \\
\text { Silurian and Devonian } \\
\text { ages (SD) }\end{array}$ & $\begin{array}{l}\text { l'Oued Group: } \\
\text { sandstones } \\
\text { (includes } \\
\text { ferruginous), } \\
\text { schists, argillites, } \\
\text { mudstones; } \\
\text { Tenemouj Group: } \\
\text { sandstones, } \\
\text { siltstones, argillites }\end{array}$ & Interior & Fractured & $5-45$ & Aquifer & Unknown & Unknown & Unknown \\
\hline
\end{tabular}


Table 3. Hydrogeologic unit characteristics--Continued.

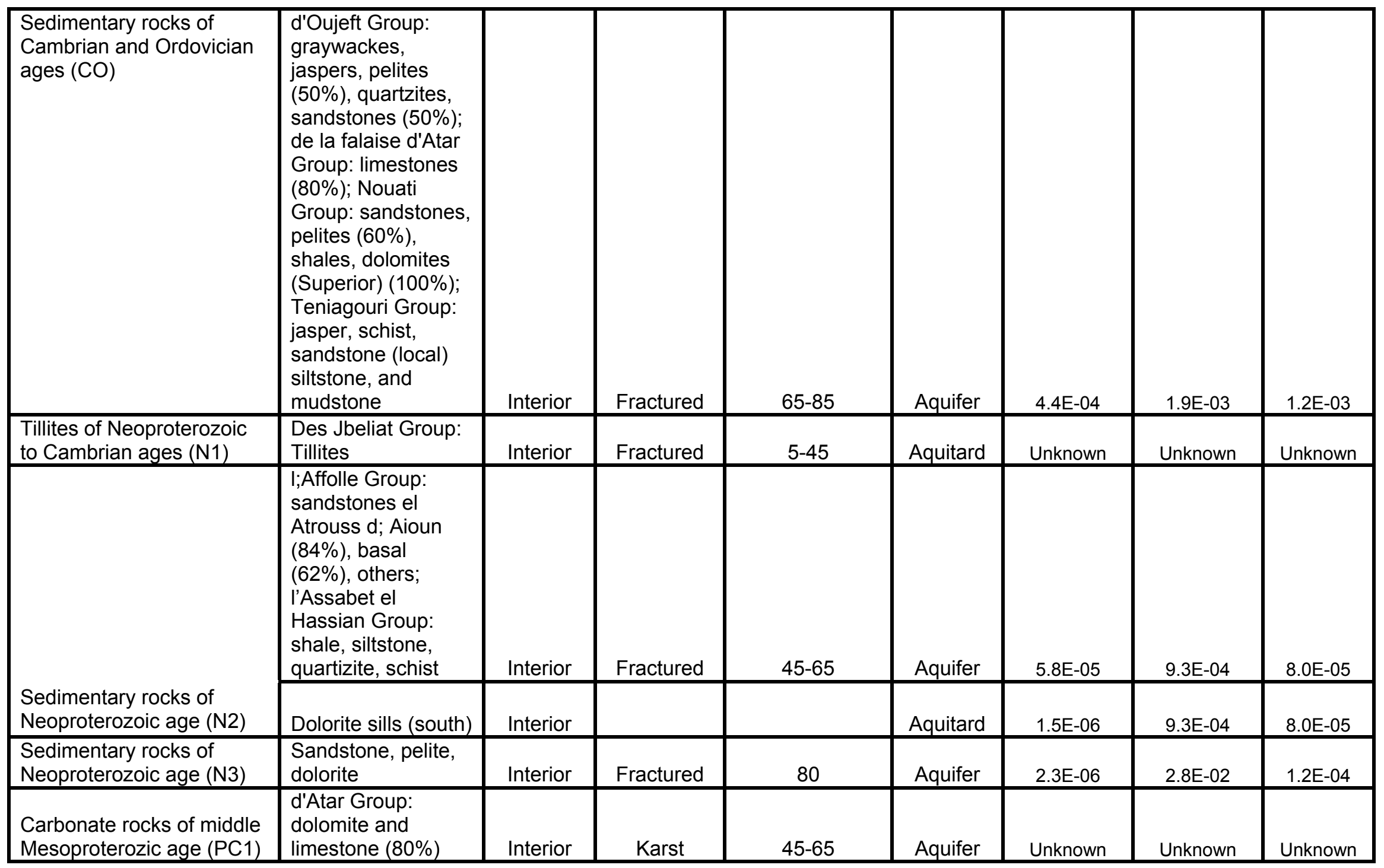


Table 3. Hydrogeologic unit characteristics--Continued.

\begin{tabular}{|c|c|c|c|c|c|c|c|c|}
\hline $\begin{array}{l}\text { Sedimentary rocks of } \\
\text { Mesoproterozoic age; } \\
\text { metasedimentary, } \\
\text { metabasalt, metarhyolite, } \\
\text { and mafic intrusive rocks } \\
\text { of Neoproterozoic age } \\
\text { (PC2) }\end{array}$ & $\begin{array}{l}\text { d'Atar group: shale, } \\
\text { quartzite, siltstone }\end{array}$ & Interior & Fractured & $45-65$ & $\begin{array}{l}\text { Aquifer in } \\
\text { north and } \\
\text { south; } \\
\text { Aquitard } \\
\text { central }\end{array}$ & 2.8E-04 & 1.2E-03 & 6.8E-04 \\
\hline $\begin{array}{l}\text { Metavolcanic and } \\
\text { sedimentary rocks of } \\
\text { Mesoarchean and } \\
\text { Neoarchean ages; } \\
\text { andesite, gneiss, granitoid, } \\
\text { metasedimentary, and } \\
\text { undifferentiated } \\
\text { sedimentary rocks of } \\
\text { Paleoproterozoic age } \\
\text { (PC3) }\end{array}$ & $\begin{array}{l}\text { Known as the } \\
\text { Reguibat Shield } \\
\text { Char Group: } \\
\text { schist, dolomite, } \\
\text { siltstone, } \\
\text { sandstones }\end{array}$ & Interior & Fractured & $0-5 \%$ & Aquitard & $2.8 \mathrm{E}-04$ & 1.2E-03 & 6.8E-04 \\
\hline $\begin{array}{l}\text { Unknown sequence of } \\
\text { rocks of }(\mathrm{U} 1)\end{array}$ & Unknown & Interior & Unknown & Unknown & Unknown & Unknown & Unknown & Unknown \\
\hline $\begin{array}{l}\text { Unknown sequence of } \\
\text { rocks of (U2) }\end{array}$ & Unknown & Interior & Unknown & Unknown & Unknown & Unknown & Unknown & Unknown \\
\hline Mauritania (all data) & & & & & & 4.0E-06 & $6.9 \mathrm{E}-02$ & 2.1E-03 \\
\hline
\end{tabular}

${ }^{1}$ Equivalent rock units in parenthesis.

${ }^{2}$ Annex 1: Echelles stratigraphiques.

${ }^{3,4}$ Type and nature of aquifer determined based on near-surface $(<100 \mathrm{~m}$ depth) pump tests; information retrieved from SIPPE2 Access database.

${ }^{5}$ Productivity percentage of drillholes that produce water greater than $1 \mathrm{~m}^{3} \mathrm{hr}^{-1}$.

${ }^{6}$ Transmissivity values (149) retrieved from SIPPE2 Access database.

${ }^{7}$ Transmissivity values characteristic of dolorites retrieved from SIPPE2 Access database.

${ }^{8}$ Transmissivity values characteristic of pellites retrieved from SIPPE2 Access database.

${ }^{9}$ Presence of dolorites interpreted using filtered aeromagnetic images. 
Table 4. Aquifer characteristics.

\begin{tabular}{|l|l|l|l|l|l|l|l|}
\hline \multirow{2}{*}{ Formation lithology } & \multirow{2}{*}{ Age } & \multicolumn{3}{|c|}{ Transmissivity $\mathbf{1}^{1,2}\left(\mathbf{m}^{2} \mathbf{h r}^{-1}\right)$} & \multicolumn{3}{c|}{ Conductivity $^{3}\left(\mathbf{m ~ h r}^{-1}\right)$} \\
\cline { 3 - 8 } & & Minimum & Maximum & Median & Minimum & Maximum & Median \\
\hline & & & & & & & \\
\hline Dolorite & & $1.50 \mathrm{E}-06$ & $9.31 \mathrm{E}-04$ & $7.95 \mathrm{E}-05$ & $6.69 \mathrm{E}-04$ & $6.69 \mathrm{E}-04$ & $6.69 \mathrm{E}-04$ \\
\hline Dolomitic limestone & & $1.50 \mathrm{E}-04$ & $1.50 \mathrm{E}-04$ & $1.50 \mathrm{E}-04$ & $1.00 \mathrm{E}-05$ & $1.00 \mathrm{E}-05$ & $1.00 \mathrm{E}-05$ \\
\hline Granite & & $1.00 \mathrm{E}-02$ & $1.00 \mathrm{E}-02$ & $1.00 \mathrm{E}-02$ & unknown & unknown & unknown \\
\hline Gravel & & $1.73 \mathrm{E}-04$ & $2.20 \mathrm{E}-02$ & $6.55 \mathrm{E}-04$ & $1.49 \mathrm{E}-05$ & $1.25 \mathrm{E}-03$ & $1.05 \mathrm{E}-04$ \\
\hline Jasper & & $5.00 \mathrm{E}-04$ & $5.00 \mathrm{E}-05$ & $5.25 \mathrm{E}-04$ & unknown & unknown & unknown \\
\hline Limestone & $1.10 \mathrm{E}-02$ & $2.30 \mathrm{E}-03$ & $6.65 \mathrm{E}-03$ & $1.10 \mathrm{E}-04$ & $3.10 \mathrm{E}-04$ & \\
\hline Pelite & & $1.50 \mathrm{E}-06$ & $9.31 \mathrm{E}-04$ & $7.95 \mathrm{E}-05$ & unknown & unknown & unknown \\
\hline & & $3.10 \mathrm{E}-04$ & $3.10 \mathrm{E}-04$ & $3.10 \mathrm{E}-04$ & $4.57 \mathrm{E}-06$ & $1.77 \mathrm{E}-05$ & $8.43 \mathrm{E}-06$ \\
\hline Quartzite & $2.38 \mathrm{E}-05$ & $2.38 \mathrm{E}-05$ & $2.38 \mathrm{E}-05$ & unknown & unknown & unknown \\
\hline & & $6.83 \mathrm{E}-04$ & $6.83 \mathrm{E}-04$ & $6.83 \mathrm{E}-04$ & unknown & unknown & unknown \\
\hline Sand & Other & $4.87 \mathrm{E}-05$ & $1.40 \mathrm{E}-02$ & $1.02 \mathrm{E}-03$ & $4.00 \mathrm{E}-06$ & $1.76 \mathrm{E}-04$ & $5.00 \mathrm{E}-05$ \\
\hline Sandstone & Proterozoic & $2.31 \mathrm{E}-06$ & $2.80 \mathrm{E}-02$ & $1.25 \mathrm{E}-04$ & $1.89 \mathrm{E}-06$ & $1.89 \mathrm{E}-06$ & $1.89 \mathrm{E}-06$ \\
\hline & Other & $4.40 \mathrm{E}-04$ & $8.20 \mathrm{E}-03$ & $1.95 \mathrm{E}-03$ & $1.10 \mathrm{E}-05$ & $3.10 \mathrm{E}-04$ & $1.10 \mathrm{E}-04$ \\
\hline Schist & Proterozoic & $1.90 \mathrm{E}-03$ & $1.90 \mathrm{E}-03$ & $1.90 \mathrm{E}-03$ & $1.00 \mathrm{E}-04$ & $1.00 \mathrm{E}-06$ & $5.05 \mathrm{E}-05$ \\
\hline & & $2.80 \mathrm{E}-04$ & $1.15 \mathrm{E}-03$ & $6.82 \mathrm{E}-04$ & & & \\
\hline & & $7.29 \mathrm{E}-04$ & $5.50 \mathrm{E}-05$ & $3.92 \mathrm{E}-04$ & unknown & unknown & unknown \\
\hline
\end{tabular}

${ }^{1}$ Transmissivity $=$ hydraulic conductivity $*$ total thickness of permeable units

${ }^{2}$ Transmissivity values (149) retrieved from SIPPE2 Access database.

${ }^{3}$ Permeability values (84); 79 of which were located in the coastal Continental Terminal Basin. 
Table 5. Water quality characteristics.

\begin{tabular}{|c|c|c|c|c|c|}
\hline \multirow[b]{2}{*}{ Statistic } & \multicolumn{4}{|c|}{ Dissolved Element } & \multirow{2}{*}{$\begin{array}{c}\text { Parameter } \\
\text { Dissolved } \\
\text { oxygen }\end{array}$} \\
\hline & Bicarbonate & Nitrate & Sulfate & $\begin{array}{l}\text { Dissolved } \\
\text { solids }^{1}\end{array}$ & \\
\hline Number of samples & 281 & 391 & 196 & 746 & 22 \\
\hline Minimum $\left(\mathrm{mg} \mathrm{L}^{-1}\right)$ & 2 & $0(11)^{2}$ & $0(14)$ & 1 & $0(3)$ \\
\hline Maximum (mg L $\left.{ }^{-1}\right)$ & 896 & 115 & 1900 & 35,000 & 17.6 \\
\hline Mean (mg L $\left.{ }^{-1}\right)$ & 242.2 & 4.9 & 96.8 & 3952 & 4.6 \\
\hline Standard deviation $\left(\mathrm{mg} \mathrm{L}^{-1}\right)$ & 44 & 11.8 & 195.3 & 9867 & 3.8 \\
\hline Median $\left(\mathrm{mg} \mathrm{L}^{-1}\right)$ & 189 & 1.15 & 35.1 & 542 & 4 \\
\hline
\end{tabular}

${ }^{1}$ Dissolved solids estimated using nonlinear regression relation established using for 285 samples.

${ }^{2}$ Parenthesis indicates number of values at or below limit of detection. 


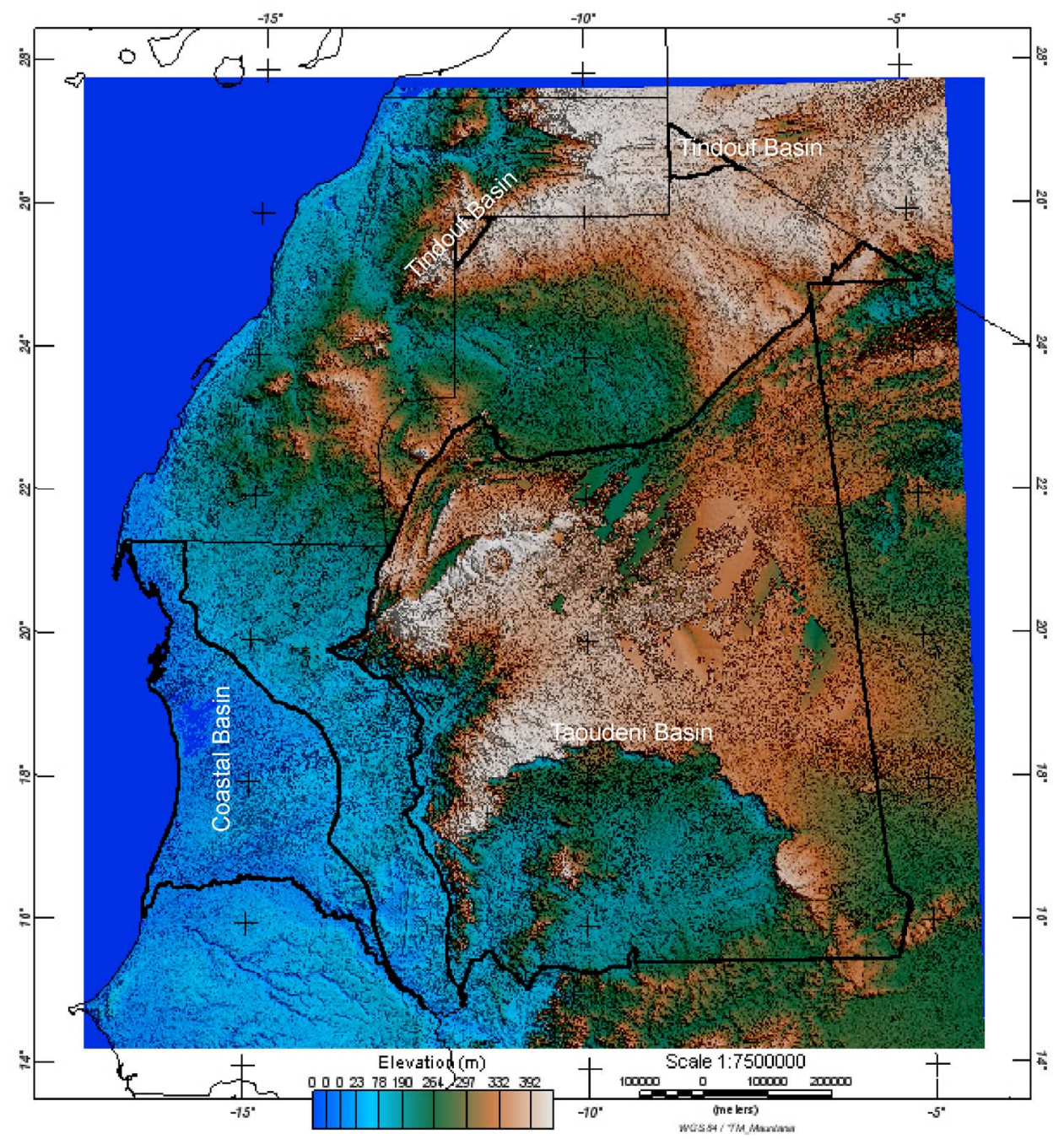

Figure 1. Color-shaded relief image of topography from SRTM and GTOPO data. Thick black lines indicate ground-water basin boundaries. 


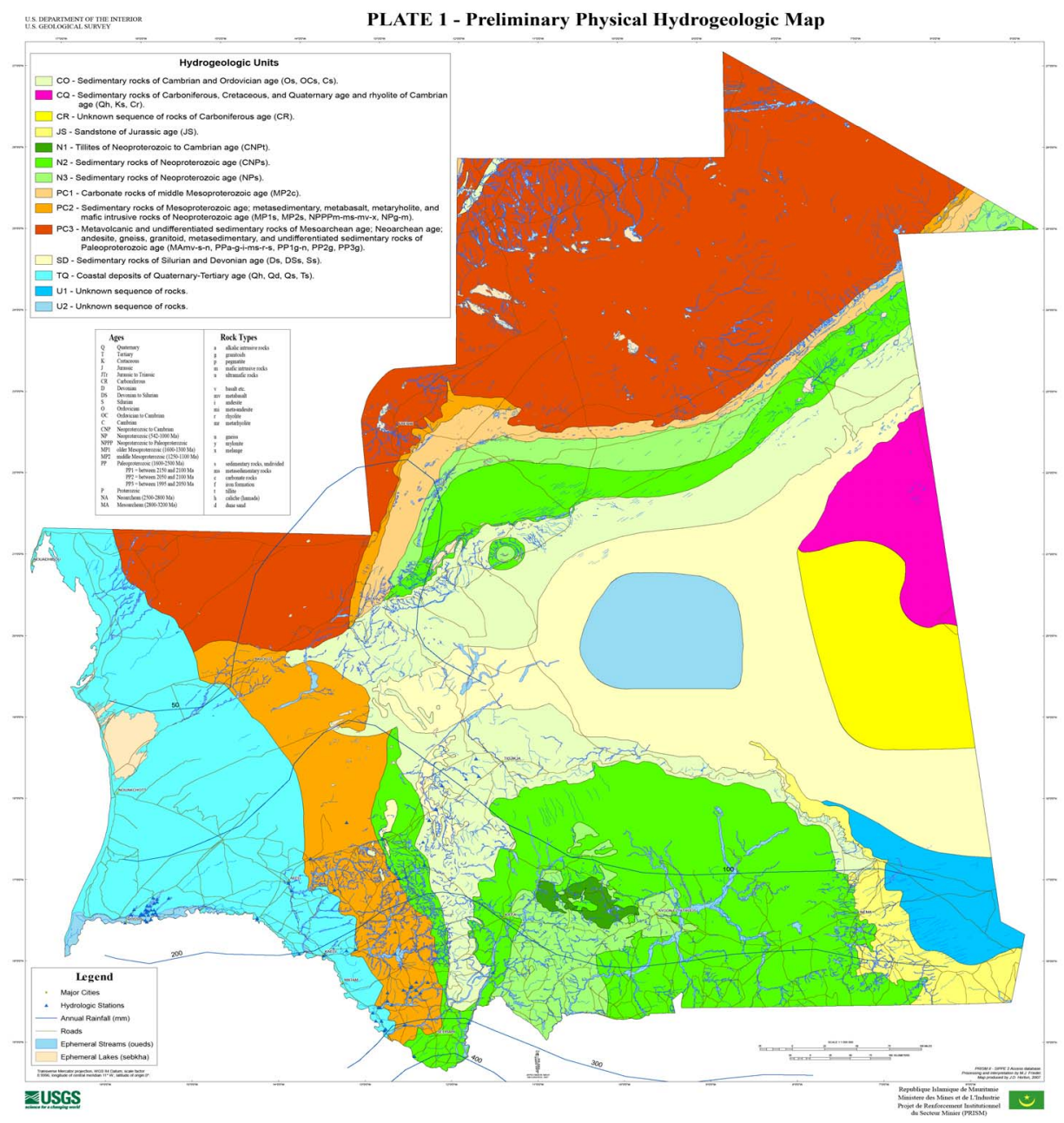

Figure 2. Physical hydrogeologic map showing hydrogeologic units mapped across Mauritania together with principal streams, lakes, annual rainfall, and cities. 


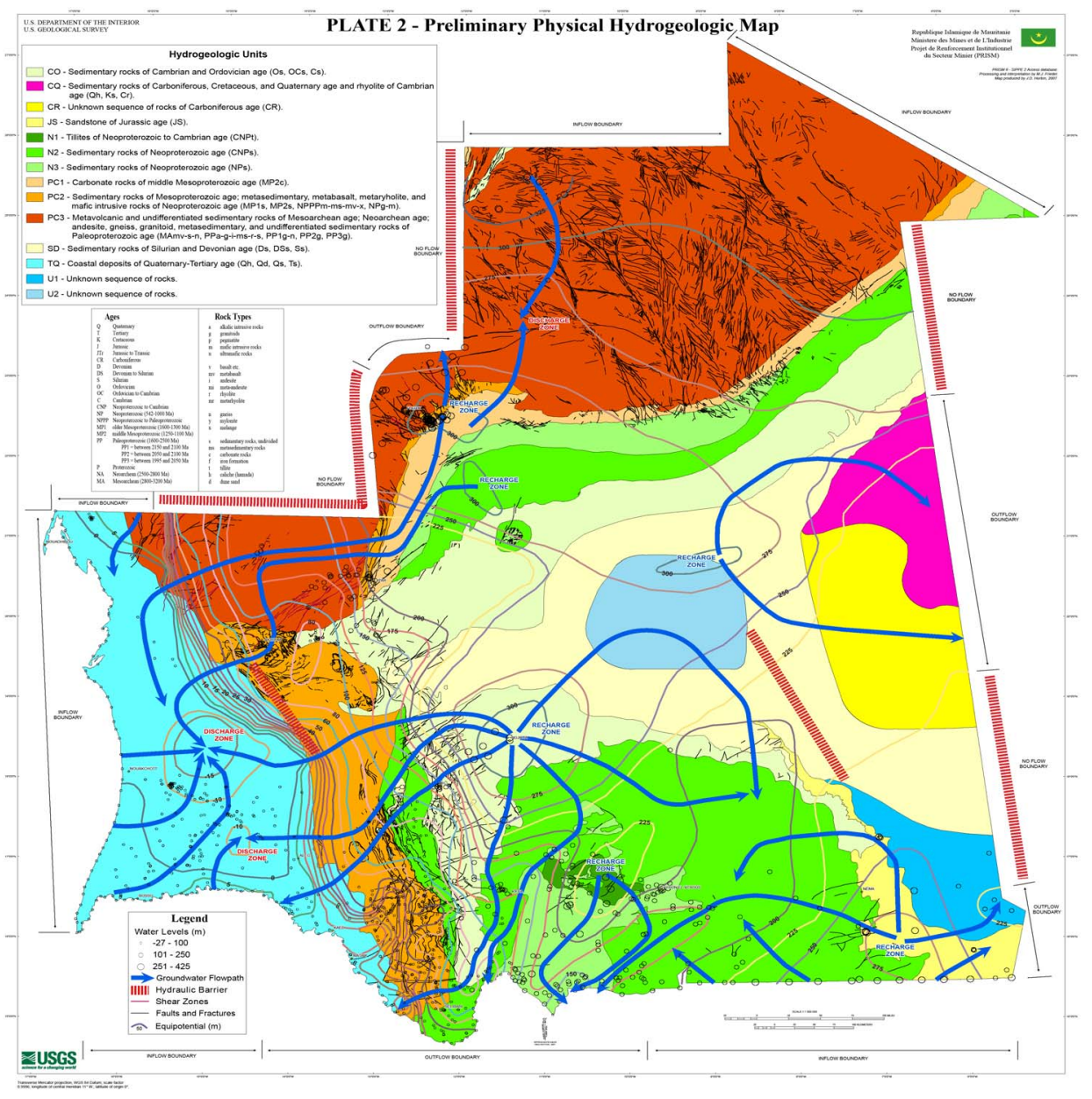

Figure 3. Physical hydrogeologic map showing equipotentials of hydraulic head (potentiometric surface), ground-water flow paths, recharge and discharge zones, and flow conditions along country boundary. 


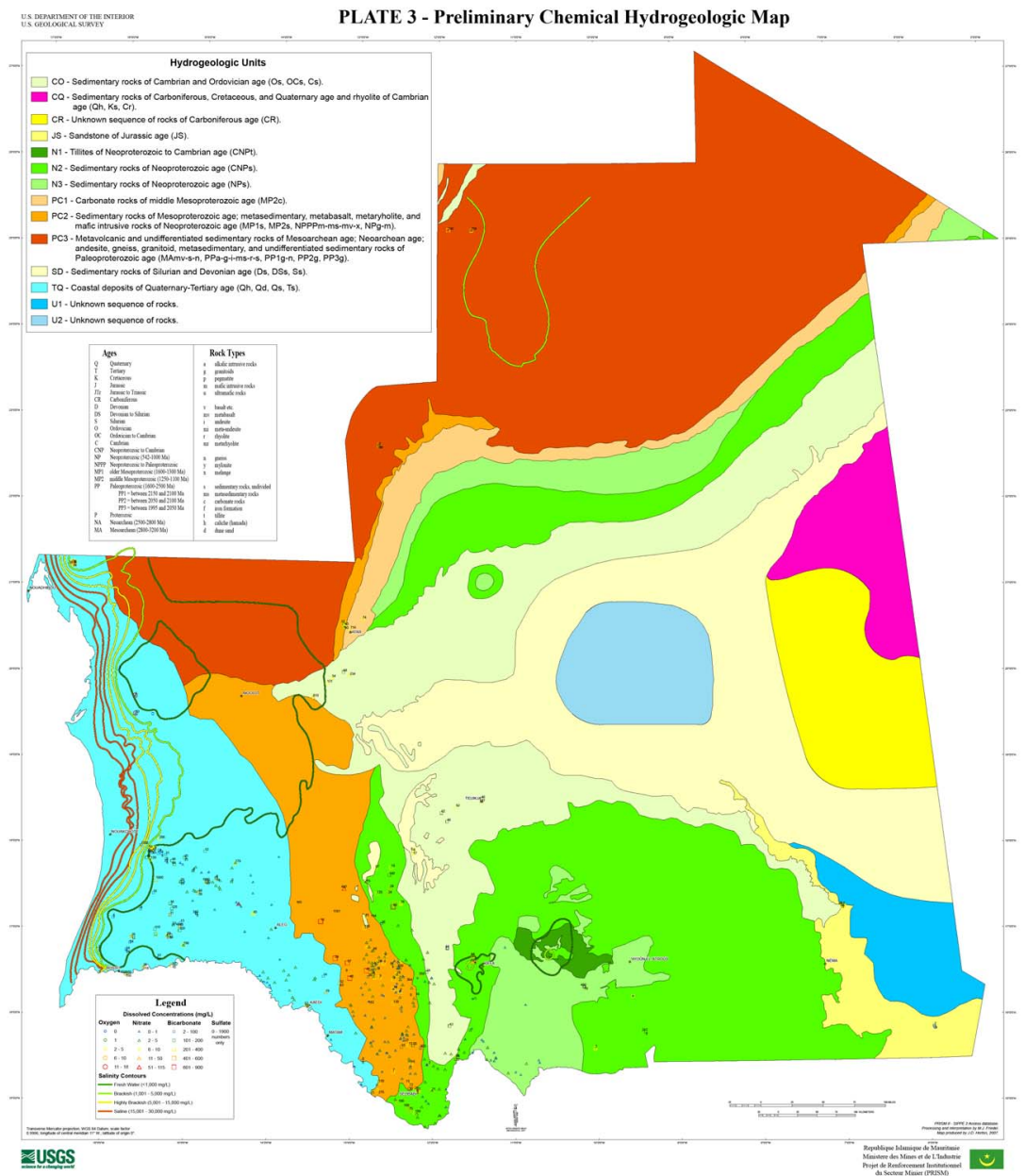

Figure 4. Chemical hydrogeologic map illustrating the occurrence and distribution of water quality in Mauritania. 


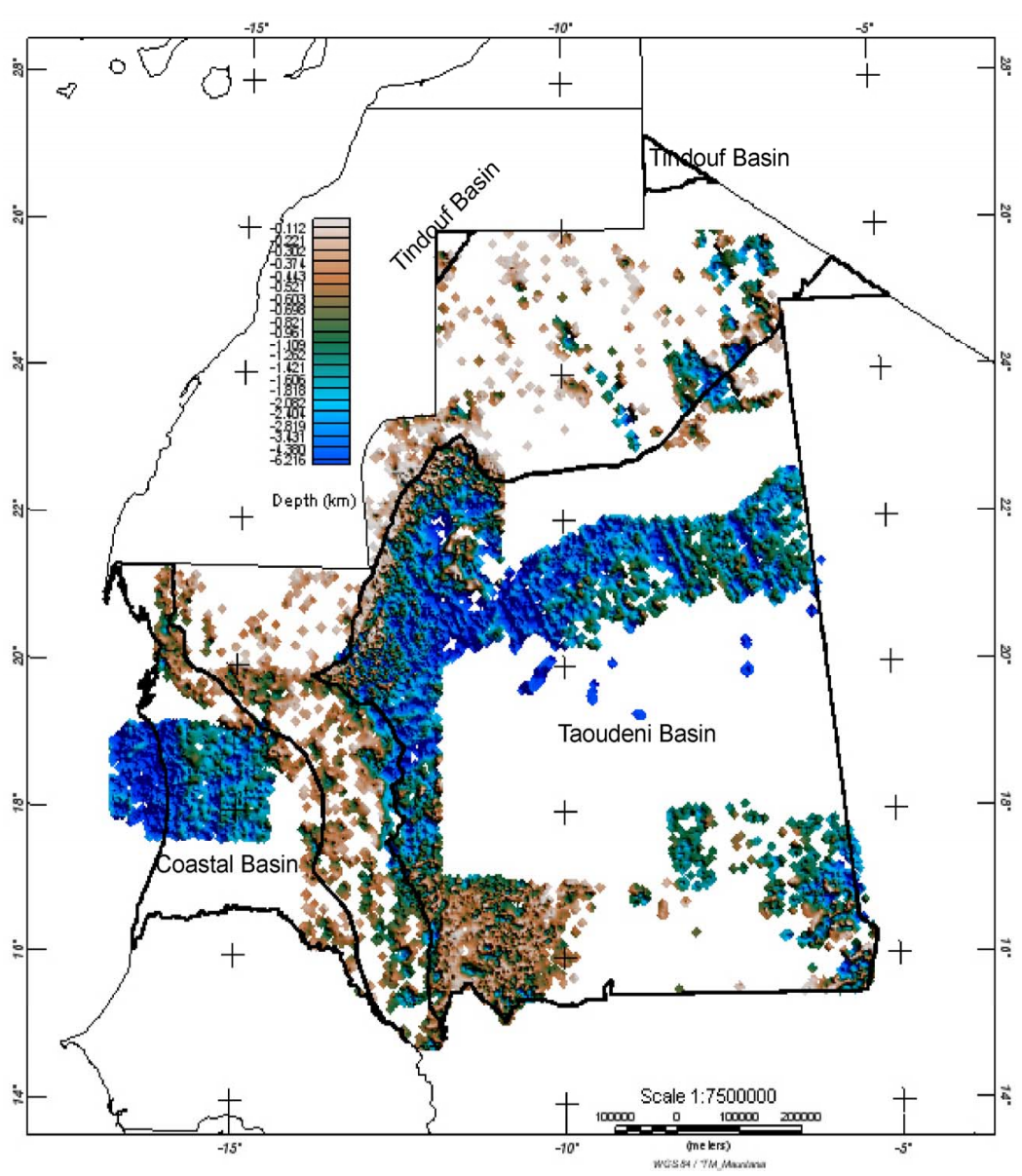

(a)

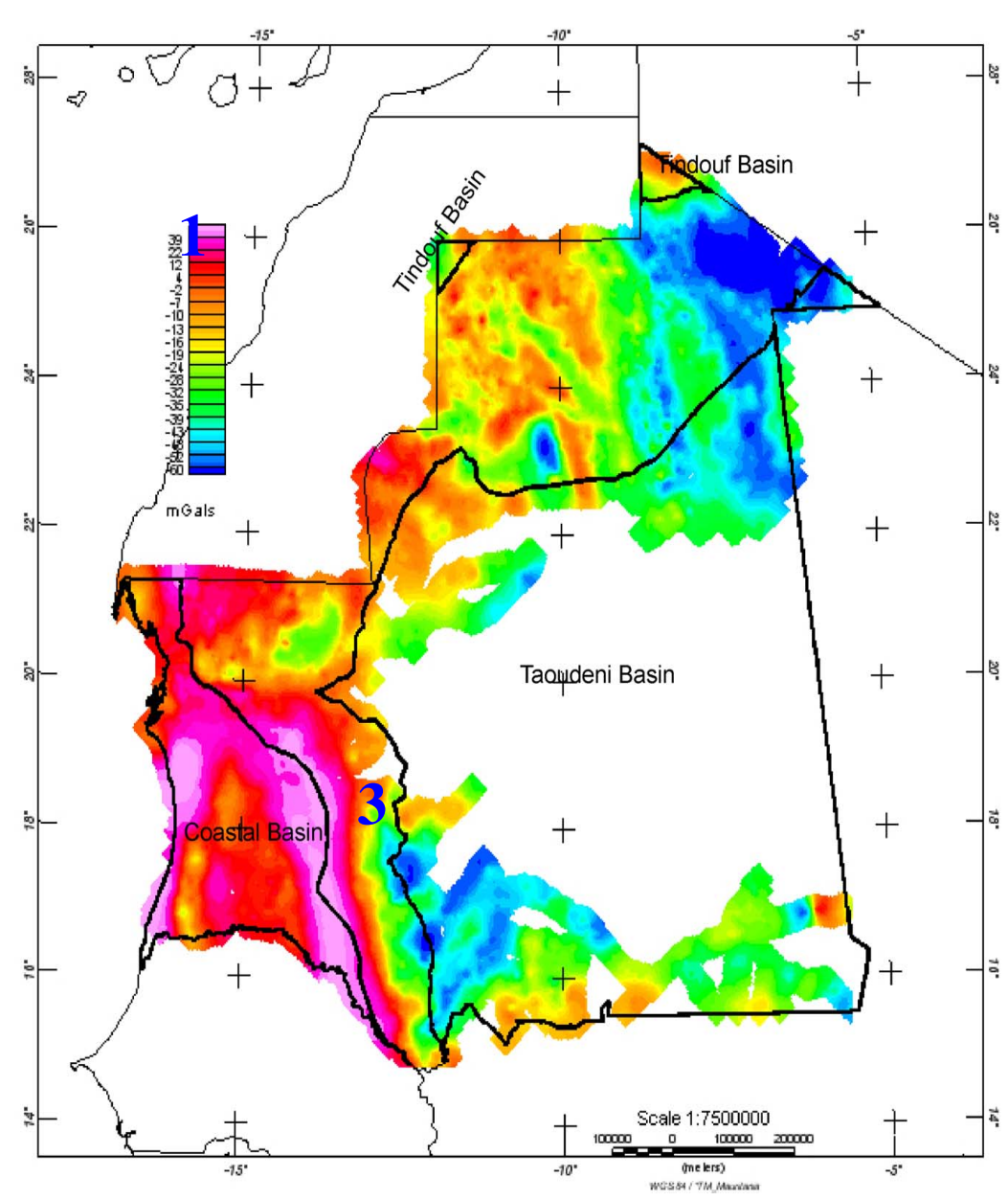

(b)

Figure 5. Geophysical imaging: (a) Color-shaded relief image of gridded depth estimates from the merged new and UN data using the Extended Euler method (Phillips, 2002). A structural index of 0 and a window size of 7 (1225 m) were used. (b.) Simple Bouguer gravity map of Mauritania, reduced using a density of $2.67 \mathrm{~g} / \mathrm{cm}^{3}$. Gravity data courtesy of M. Albouy. 